\title{
On the Mental Representation of (Un)Healthy Tooth: (Un)Healthy Tooth Profiles among Children
}

\author{
Maria R. Dias ${ }^{1} \&$ Nádia P. Simões ${ }^{2}$ \\ ${ }^{1}$ Egas Moniz Higher Education School of Health, Caparica, Portugal \\ ${ }^{2}$ Egas Moniz Multidisciplinary Research Center in Health Psychology, Caparica, Portugal \\ Correspondence: Maria R. Dias, Egas Moniz Centro de Investigação Multidisciplinar em Psicologia da Saúde, \\ Campus Universitário, Quinta da Granja, Monte de Caparica, 2829-511, Caparica, Portugal. Tel: \\ 351-936-93-6101. E-mail: mariadorosario.dias@gmail.com
}

Received: October 10, 2015

Accepted: November 7, 2015

Online Published: Feburuary 2, 2016

doi:10.5539/jedp.v6n1p110

URL: http://dx.doi.org/10.5539/jedp.v6n1p110

This study was supported by a grant from Pierre Fabre Portugal.

\begin{abstract}
Objectives: A descriptive study of exploratory character with the objective to determine the representation of a healthy tooth and an unhealthy tooth, associated with the concept of dental decay. Methods: Children of both genders (880), distributed in six age groups of low socio-economic level, some already having prior contact with the dentist and others not. Three instruments were used: a sociodemographic questionnaire, pictograms representation protocols and drawing content analysis grid. Results: Content analysis on the drawings indicates significant discrepancies, inherent to the pictorial profiles. Conclusion: The results point to the need of developing educative tools for oral health.
\end{abstract}

Keywords: health education, healthy tooth, tooth decay

\section{Introduction}

Tooth decay is currently a public health issue, not because it triggers a high mortality rate, but due to the high incidence of its morbidity rate in the European region. Between 1999 and 2006, Portugal saw a significant reduction in the percentage of children suffering from tooth decay, with the percentage of six-year-old children free from tooth decay increasing from 33\% to $51 \%$. In spite of this improvement, one cannot lose sight of the goal set by the World Health Organization: that the percentage of six-year-old children free from tooth decay in the European region by the year 2020 is no lower than $80 \%(1,2)$. Tooth decay is an infectious disease of multifactorial etiology that affects every age group in the course of a lifetime. It is, however, during childhood, that a concern with the eruption of deciduous teeth is triggered (3). Thus, in the context of tooth decay prevention and oral health promotion, to inform, that is, to provide and disseminate information, is of paramount importance (4-6), but it is also highly pertinent to understand the extent to which children actually perceive and internalize such informative contents that would lead them to adopt a "self-prevention" attitude (7).

In respect to data collection techniques, drawing is the earliest form of cognitive-emotional expression, and a basic and universal form of language. The use of the resource "drawing" for research purposes has been employed as a methodological guideline for qualitative research conducted in the field of health studies (8-12). As an empiric assessment tool, drawing presents itself as a consummate projective instrument, for it is a symbolic vehicle that inter-subjectively brings to light the inner world of the child (13-19). At our institution, several research projects in Paediatric Dentistry (20-23) and Paediatric Psychology have used the resource "drawing" as an empirical instrument (24-26) as well as a ludic-pictorial material supported in the ludic (re)configuration of the dentist doctor's face $(27,28)$ and in the dramatization with finger puppets $(29)$ contextualized in oral health promotion. It is undeniable that, at the medical appointment setting, the direct motivation when using ludic-pictorial material is a "major resource" (21) for purposes of oral health education.

In the present study, we have assumed the premise that the content analysis of drawings rendered by children aged between 4 and 9 years (attending either elementary school or kindergarten) would elicit differences as to those 
children's internalized mental representations on the concept of tooth decay. Such expected differences may further allow us to put together objective pictorial profiles of what constitutes a "healthy tooth" and an "unhealthy tooth".

\section{Methods}

For purposes of satisfying the research's analytical model, we have designed a cross-sectional, descriptive study of exploratory character that follows a methodological strategy of qualitative type, based on content analysis of drawings collected, combined with quantitative parameters.

Participants: The sample for this study, recruited in school context, comprehends a total of 880 school-aged children of both sexes ( $51.7 \%$ girls; $48.3 \%$ boys), distributed into six age-groups ( $4 \mathrm{YG}=97 ; 5 \mathrm{YG}=147 ; 6 \mathrm{YG}=168$; $7 \mathrm{YG}=155 ; 8 \mathrm{YG}=164 ; 9 \mathrm{YG}=149) .611$ of the children participating in our study $(69.4 \%)$ had the experience of having been seen by a dentist $(4 \mathrm{YG}=36.1 \% ; 5 \mathrm{YG}=47.6 \% ; 6 \mathrm{YG}=69.6 \% ; 7 \mathrm{YG}=70.3 \% ; 8 \mathrm{YG}=90.2 \% ; 9 \mathrm{YG}=88.6 \%)$, whereas 269 children $(30.6 \%)$ had never had that experience $(4 \mathrm{YG}=63.9 \% ; 5 \mathrm{YG}=52.4 \% ; 6 \mathrm{YG}=30.4 \%$; $7 \mathrm{YG}=29.7 \%$; $8 \mathrm{YG}=9.8 \%$; $9 \mathrm{YG}=11.4 \%$ ).

Instruments: i) Sociodemographic Questionnaire — collects data regarding the participant child's age, sex, school level, and whether or not they had ever had a dental appointment; ii) Pictorial Representation Protocols ("Healthy Tooth" and "Unhealthy Tooth") consisting in two A4 sheets-one where the child is to draw, with a graphite pencil, the pictogram corresponding to a healthy tooth; the other, where they are to illustrate an unhealthy tooth. iii) Drawing Content Analysis Grid - the drawings were subjected to a content analysis using a grid of analytical categories specifically designed to the present study. This instrument-grid encompasses five elementary categories: C1-Tooth figure drawing; C2-Anthropomorphised face drawing; C3-Dental arch; C4-General appearance of the teeth; C5-Accessories, a category encompassing 26 additional analytical subcategories.

Procedures: Data were collected in two distinct, though consecutive, moments: (i) each child was initially asked to draw a healthy tooth in the first sheet of paper, and to draw an unhealthy tooth in the following sheet; (ii) once both pictograms were finished, the child was then asked three questions aimed at determining their mental representation of "healthy tooth", "unhealthy tooth" and "tooth decay". Nonetheless, the current study will only address those results which concern the content analysis of the drawings. Quantitative data were analysed using SPSS (Statistical Package for the Social Sciences), version 19.0 for Windows.

All the procedures were approved by the Ethics Committee of our Institution.

\section{Results}

The data collected in the present exploratory study show a higher prevalence of participants (children) who have had dental appointments. There is also, overall, a higher prevalence of children in the 4-5 years age-group with no experience of dental appointments. Interestingly, from the age of six years onwards, the number of children who have been seen by a dentist is substantially high.

Regarding children that have been seen by a Dentist, a healthy tooth pictorial representation shows a one-dimensional single tooth $(92.6 \%)$, of small size (55\%), with a rectangular shape (58.4\%). It is a stylized tooth $(82.1 \%)$, one that is not frequently anthropomorphized $(88.7 \%)$ or that present accessories. When it is anthropomorphized, the drawings show happy faces (79.1\%), with eyes and mouths. Most of all, it is a clean tooth, characterized by the absence of spots, holes, fractures and vermin, that presents roots $(59 \%)$ and whose surface is smooth (73.2\%).

As to children that have not been seen by a Dentist, the profile of an healthy tooth is of a one-dimensional (91.4\%) single tooth (93.7\%), of small size (67.3\%) and rectangular shape (61.7). It is a stylized tooth (65\%), one that is not anthropomorphized (93.7\%). Similar to the children that have been at a dentist appointment, the tooth is clean, comprised by the absence of spots, holes, fractures and vermin, has roots $(50 \%)$ and presents a smooth surface (91.4\%). Although typically accessories are not imprinted in the drawings, some of the children draw a tooth brush and tooth paste, thus, showing that they may possess the notion that a clean tooth is synonymous of a healthy tooth.

Results referring to the profile for a ill tooth show that children that have been seen by a Dentist tend to represent a one-dimensional $(93.6 \%)$ single tooth $(89.8 \%)$, of small size (51.6\%) and rectangular shape (58.6\%). It is typically a stylized tooth $(83 \%)$, with fragile investment $(82.3 \%)$ and non-anthropomorphized $(87.4 \%)$. The percentage that does anthropomorphized the tooth, draw sad faces (98.7\%), with tears on the affected piece. The ill tooth is characterized by a smooth surface $(73.8 \%)$ but one that shows the presence of spots and risks $(54.3 \%)$, holes, fractures, vermin, and filling (13.7\%) as a sign of the affected surface. 
As to the children that have not been seen by a Dentist, the profile of an ill tooth is of a one-dimensional (91.4\%) single tooth $(96.3 \%)$, of small size $(71.7 \%)$ and rectangular shape $(49.8)$. It is a stylized tooth $(64.3 \%)$, one that is not frequently invested $(72.9 \%)$, mainly by children aged 4 and 5 years old. Although anthropomorphization is fragile, it tends to be made by 7 and 9 year old children $(7.4 \%$ ) - projecting sad faces. If the healthy profile in children that have already been at the dentist appointment, in this group only 2 children draw tears. The tooth is one-dimensional (93.3\%), of smooth surface (90.7\%), characterized by the presence of spots, risks, holes, fractures and vermin, accompanied by fillings that represented the affected part or ill part of the tooth.

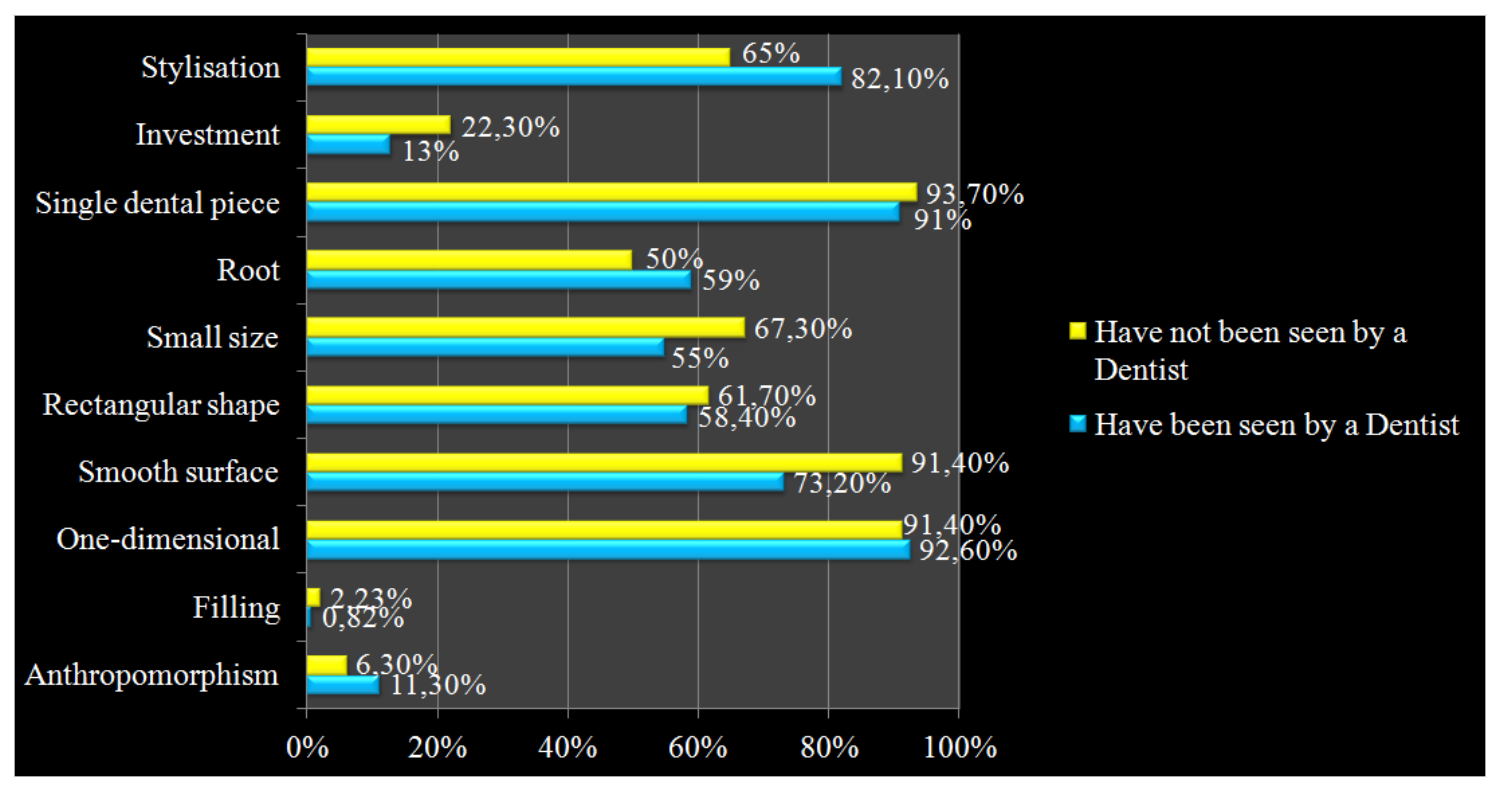

Figure 1. Pictorial representation profile of Healthy Tooth

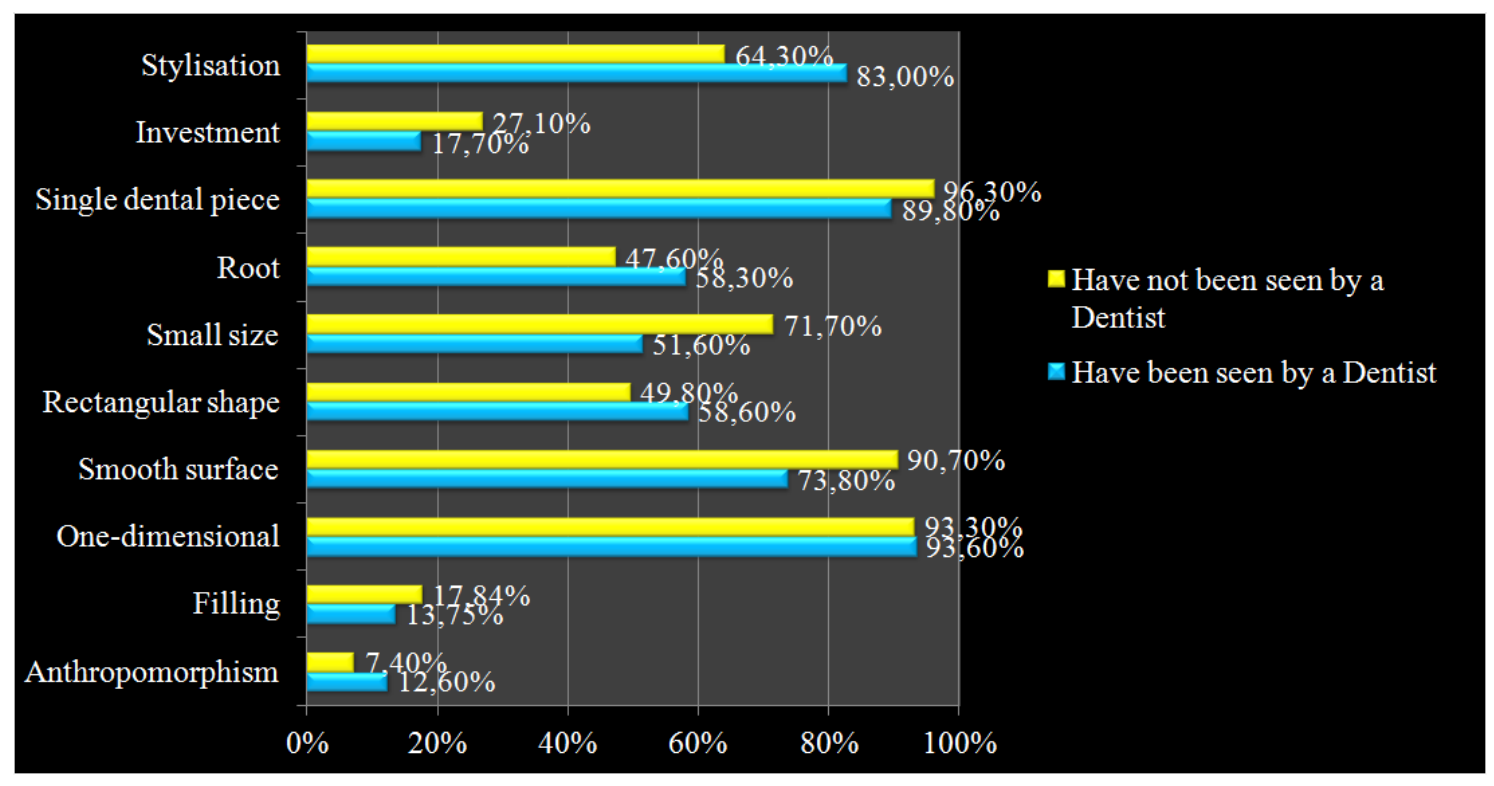

Figure 2. Pictorial representation profile of Ill Tooth 


\section{Discussion}

The pictorial representation of healthy tooth (Figure 3) is mainly suggestive of a clean tooth: no signs of dirtiness/maculation, and completely free from stains or blemishes, holes/cavities or fractures (category: appearance). This suggests that children cognitively perceive and/or associate a clean tooth to a healthy tooth. Although in diminutive proportion, those children who have, in their symbolic representations, anthropomorphised their drawing (9.77\% of participants), depicted the figure of the "healthy tooth" with a joyful countenance, sketching the anatomic features of a human face, with eyes, nose and mouth. Anthropomorphised representations were more patent in drawings made by children who had dental appointments.

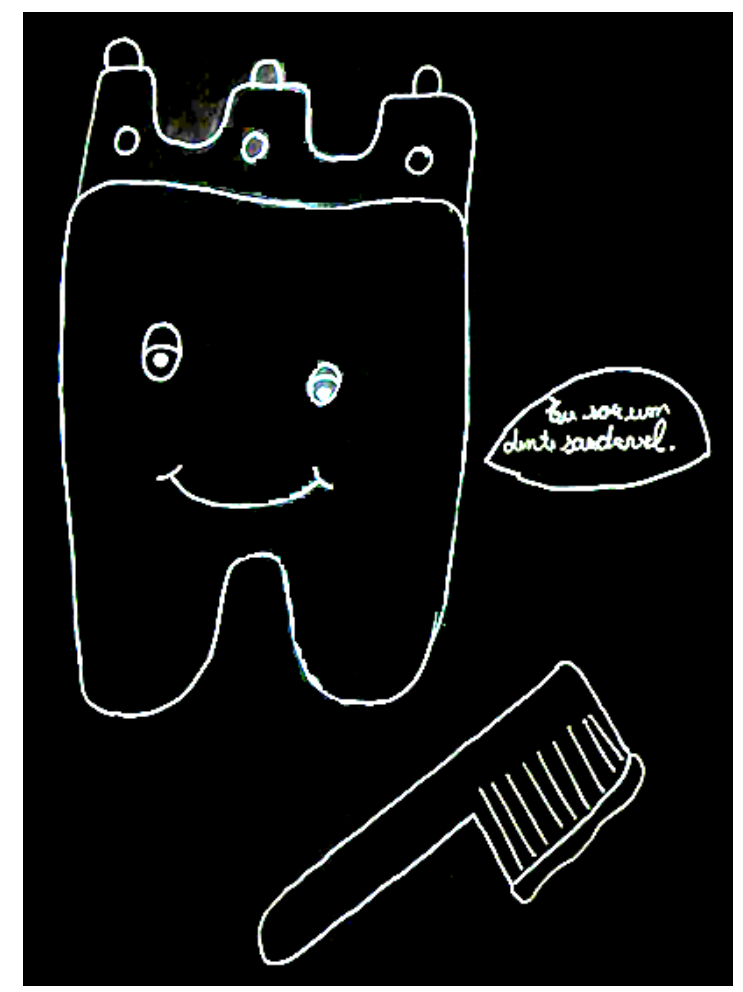

Figure 3. Drawing of a Healthy Tooth

In pictorial representations of unhealthy tooth (Figure 4), and as to those features under the category appearance, the figure of the tooth is soiled by the presence of holes/cavities and lines/stains, with fillings (underlined in graphite) and fractures. Also associated to the unhealthy tooth profile is the pictorial representation of bacteria (classed under the subcategory "worm"/caries); interestingly, when the figure "unhealthy tooth" is sketched in anatomically anthropomorphised fashion, it is depicted as an emotionally "sad" tooth. It is also worth mentioning that those who pictorially represent tears associated to the anthropomorphised face of the "unhealthy tooth" are the children with previous experience of dental appointments. This seems to suggest that such children have already internalised in their mental representation of "unhealthy tooth" the pain inherent to the condition. We would thus argue that, because most children in our sample have had dental appointments, and assuming such appointments to have occurred in the sequence of caries, they are then able to identify beforehand some of the signs of a carious lesion. 


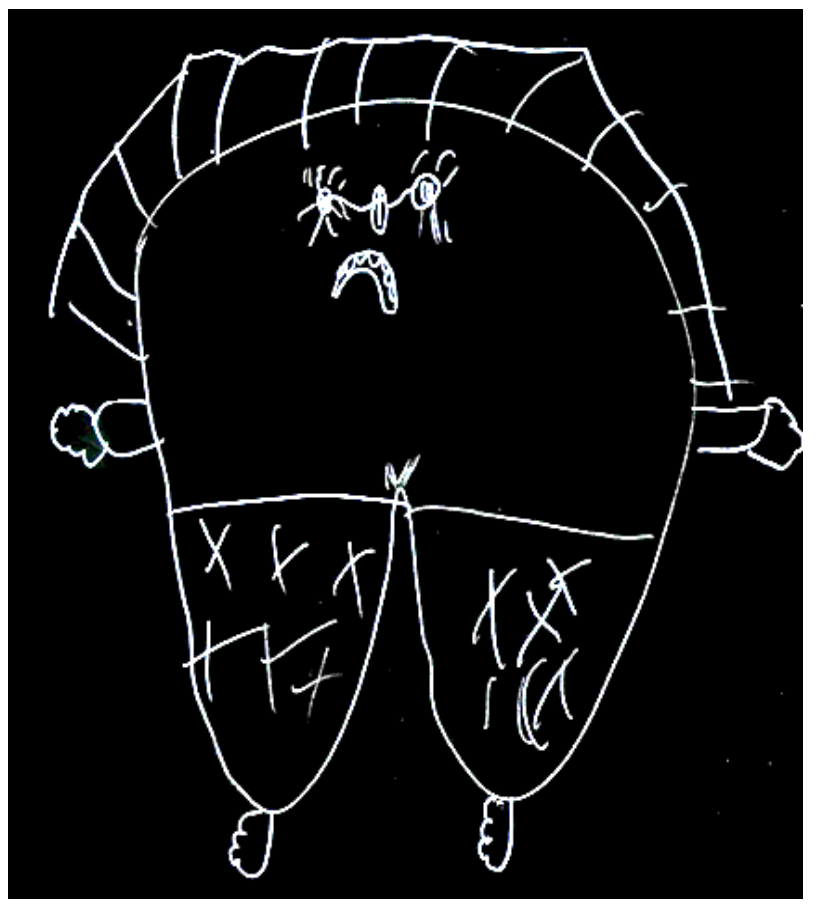

Figure 4. Drawing of an Ill Tooth

Overall, results show that, regardless of having or not having had dental appointments, it lies in every child the cognition that healthy tooth is always associated to "clean tooth". Along the same lines, and when we look to the elementary category accessories, we see that, despite it being an underrepresented feature in the drawings collected (3.41\% of the total), subcategories toothpaste and toothbrush, as hygiene instruments, are the elected ones, particularly by children aged $6+$ years, as prevalent in terms of added components. We would thus infer that the surveyed children exhibit the basic knowledge that their oral health is necessarily contingent on preventive procedures of hygiene. To represent a "happy" tooth as a clean tooth seems to project the psychological representation of the subject him/herself, for a happy tooth (and, ultimately, a happy mouth) seems to represent a happy self, which in turn will manifest in every sense, not only in a state of general well-being, as also in the absence of pain and suffering, as well as in the lack of aesthetical self-consciousness, likely to affect the child's self-image.

\section{Conclusion}

This exploratory study in the field of oral health promotion aims of being a contribution to the creation of playing-pedagogical instruments in the child's clinical settings. At the same time, to encourage the therapeutic tie as an opposite of the traditional image of the Dentist, who "wants to pull one's teeth".

Analysis of the pictorial contents of the drawings made by the children participating in our study denotes significant discrepancies, inherent to the illustration profiles of healthy tooth versus unhealthy tooth. Such discrepancies bear implications at the level of oral health promotion and oral disease prevention, suggesting the need to create ludic-pedagogic instruments for oral health education in very early development stages. In this context, some health education instruments were developed by the team of investigators from our institution. Restructuring "clinic tools" and preparing playing related material as the Figurative Masks used by Paediatric Dentists or a Finger-puppet Theatre Movie are symbolic representatives for the clinical-therapeutic reality, are examples of things that are outlined. Specifically, the Finger-puppet Theatre Movie appears as a child's "imagination performer", at the level of information given on oral health, namely in what concerns the oral routine of hygiene and the promotion of healthy eating behaviours. Nonetheless, and more directed to children that haven't been at the dentist, another ludic-pedagogic instrument, composed by a set of materials that reproduce the typically used real instruments in the appointment setting, allows, through play sessions, children to find out some facts about teeth, about baby and permanent teeth, oral health habits, what are the procedures done in the appointment 
setting and why they are done-thus, promoting the understanding of the dental treatment and encouraging children to cooperate with the dentist when they go there.

We want to encourage the dentist to create spaces, leisure times and playing materials of relational-interactive nature, that may mediate the clinical setting and the good practices of health provided in dental care.

\section{References}

Cariola, T. C., \& Martins, R. P. (2001). O desenho da figura humana por crianças de visão subnormal. Pediatr Mod., 37(12), 658-664.

Cariola, T. C., Cardia, M. F., \& Palamin, M. E. (2001). O desenho da figura humana na evolução clínica da arteterapia com crianças deficientes auditivas. Pediatr Mod., 37, 75-92.

DGS. (2000). Estudo nacional da prevalência da cárie dentária na população escolarizada.

Di Leo, J. (1987). A Interpretação do Desenho Infantil. Porto Alegre, Brazil: Artes Médicas.

Dias, M. R, Duque, A., \& Gonçalves, S. (2010). “Mens Sana in Corpore Sano”: The Concept of Health and Illness in Childhood. Cluj Napoca, Romania.

Dias, M. R. (2005). A Esmeralda Perdida: A informação prestada ao doente oncológico. Lisbon: CLIMEPSI.

Dias, M. R. (2005). Serão os Mass Media estrategas de saúde? Lisbon: CLIMEPSI.

Dias, M. R. et al. (2012). Non-verbal communication in the paediatric dentistry appointment setting. Poster Sess Present Eur Heal Psychol Soc Prague, Czech Repub.

Dias, M. R., Amorim, A., Esteves, A., Reis, F., \& Duques, A. F. (2006). Tooth fairy Myth: Child oral health education. Poster Present EACH 2006-Int Conf Healthc Abstr P1202.

Dias, M. R., Amorim, A., Freches, A., \& Guilherme, J. (2006). Masked dentist in therapeutic setting. EACH 2006-Int Conf Healthc Abstr P3105.

Dias, M. R., Duque, A., Silva, M., \& Durá, E. (2004). Promoção de saúde: O renascimento de uma ideologia? Análise Psicológica, 22(3), 463-473.

Dias, M. R., Julião, R., Reis, F., \& Duque, A. (2008). Choose the meal: A health education project on childhood food preferences. Poster Sess Present Int Conf Commun Heal Oslo, Norw.

Dias, M. R., Simões, N. P., Silva, A. R., Morais, H., Carreira, C., \& Ventura, I. (2012). "My tooth is ill”: An oral health education project. 26th Conference of the European Health Psycholgy Society, República Checa.

Dias, M., Simões, N., Cruz, J., Martins, N. (n.d.). I am Favolas: A health education instrument in dentistry. Oral Commun Sess Present 14th Estoril Vigotsky Conf Estoril, Port.

Eur Heal all Ser. (1999). WHO. Health 21: The health for all policy framework for the WHO European Regions (Vol 37, No. 3, pp. 461-475).

Fávero, M. H., \& Salim, C. M. R. (1995). A relação entre os conceitos de saúde, doença e morte: Utilização de desenho na coleta de dados. Psicol Teor e Pesqui., 11(3), 181-191.

Gazzinelli, M. F., Silva, T. C., Rodrigues, R. A., Araújo, E. G., \& Bethony, J. (2008). Representações de crianças de zona rural sobre saúde e o pesquisador: A grande saúde e o grande outro. REME Rev Min Enferm., 12(2), 153-161.

Harris, N. O., \& Christen, A. G. (1995). Primary Primitive Dentistry. Stanford, United States of America: Appleton \& Lange.

Luquet, G. H. (1987). O desenho infantil. Porto, Portugal: Livraria Civilização Editora.

Maibach, E. W., \& Parrot, R. T. (1995). Designing health messages: Approaches from communication theory and public health practice. Sage Publications.

Maldonado, F. P., Cariola, T. C., Yamada, M. O., \& Bevilacqua, M. C. (2002). O desenho da figura humana em crianças com implante coclear e escolaridade. Pediatr Mod., 39(5), 181-187.

Marcon, C. (2003). A consulta pediátrica e os aspectos comunicacionais entre o médico residente, a criança e sua família (Unpublished Master's Thesis). Universidade Federal de Santa Catarina, Florianópolis, Brazil. 
Morais, H., Dias, M. R., Ventura, I., Simões, N. P., \& Silva, A. R. (2012). Estudo exploratório sobre a comunicação não verbal no setting de consulta em odontopediatria. Poster Sess Present III Jornadas Ciências da Saúde, Monte da Caparica, Port.

Oliveira, H. A. (1993). enfermidade sob o olhar da criança hospitalizada. Cad Saúde Pública., 9(3), $326-332$. http://dx.doi.org/10.1590/S0102-311X1993000300020

Poulton, R., Thomson, W., Davies, S., Kruger, E., Brown, H., \& Silva, P. (2004). Good teeth, bad teeth and fear of the dentist. Pediatr Dent., 26(4), 316-321.

Quiles, M. J., Van-der Hofstad, C. J., Quiles, Y., \& Quiles, Y. (2004). Instrumentos de evaluación del dolor en pacientes pediátricos: una revisión (2 $2^{\mathrm{a}}$ parte). Rev Soc Esp Dolor., 11(6), 360-369.

Reis, F., Dias, M. R., \& Leal, I. (2008). A consulta no setting odontopediátrico: A percepção subjectiva do medo. Análise Psicológica., 2(XXVI), 239-250.

Simões, N. P., \& Dias, M. R. (2012). Um instrumento de intervenção: “Era uma vez o génio da fala.”. Poster Sess Present III Jornadas Ciências da Saúde, Monte da Caparica, Port.

Trinca, A. M. T. (1997). Ampliação e expansão. In W. Trinca (Ed.), Formas de investigação clínica em psicologia: Procedimentos de desenhos-estórias e procedimentos de desenhos de família com estórias (pp. 35-66). São Paulo, Brazil: Vetor.

\section{Copyrights}

Copyright for this article is retained by the author(s), with first publication rights granted to the journal.

This is an open-access article distributed under the terms and conditions of the Creative Commons Attribution license (http://creativecommons.org/licenses/by/3.0/). 